\title{
REGIME DAS INCAPACIDADES E PESSOA COM DEFICIÊNCIA
}

\author{
Guilherme Calmon Nogueira da Gama ${ }^{1}$ \\ Marina Lacerda Nunes ${ }^{2}$
}

\begin{abstract}
Resumo
O presente artigo objetiva estudar o tema da capacidade civil e suas implicações, tendo em vista as profundas mudanças legislativas operadas pela Convenção Internacional dos Direitos da Pessoa com Deficiência e pelo Estatuto da Pessoa com Deficiência (Lei no 13.146/2015), que provocaram uma releitura da teoria das incapacidades, sob a ótica da inclusão da pessoa com deficiência na sociedade e da promoção de sua dignidade e direitos fundamentais. Outrossim, trata da ressignificação do instituto da curatela e da introdução do procedimento da tomada de decisão apoiada no direito brasileiro, enfatizando a esfera existencial da pessoa.
\end{abstract}

Palavras-chaves: Capacidade civil; Pessoa com Deficiência; Inclusão; Curatela; Tomada de decisão apoiada.

\section{INTRODUÇÃO}

Em 2014, chegava aos cinemas o filme Still Alice, baseado no romance de Lisa Genoveva, que conta a história de uma professora de linguística da Universidade de Columbia - Alice Howland - que é diagnosticada com Alzheimer precoce aos 50 (cinquenta) anos e tem sua vida pessoal, profissional e familiar profundamente impactada pelos desdobramentos da doença. A atriz Julianne Moore interpreta a personagem principal e sua autêntica atuação no papel de uma paciente de Alzheimer lhe rendeu o Oscar de melhor atriz neste ano.

O Alzheimer precoce representa cerca de $10 \%$ do total de casos identificados no mundo, sendo um tipo mais raro da doença, geralmente transmitido geneticamente, que se manifesta antes dos 65 anos e caracteriza-se por um declínio rápido das funções cognitivas. O filme, que teve ampla repercussão em razão dos prêmios conquistados, retrata sensível abordagem sobre a dura realidade que enfrentam o paciente de Alzheimer e seus familiares, desde os primeiros sintomas, como lapsos de memória e desorientação espacial, até a completa alienação da pessoa.

Uma das cenas do filme reproduz o discurso de Alice num evento organizado pela Alzheimer's Association, integralmente transcrito a seguir:

\footnotetext{
${ }^{1}$ Doutor em Direito Civil pela UERJ. Professor Associado de Direito Civil da UERJ e Professor Permanente do PPGD da UNESA (RJ). Membro da Academia Brasileira de Direito Civil e do IBDFAM. E-mail: gcalmon@trf2.gov.br

${ }^{2}$ Graduada pela Faculdade de Direito da UERJ.E-mail: mlnunes@gmail.com
} 
"A poetisa Elisabeth Bishop escreveu: 'A arte de perder não é nenhum mistério; tantas coisas parecem ser cheias de intenção de perda que perdê-las não é nenhum desastre'. Eu não sou uma poetisa. Sou uma pessoa vivendo no estágio inicial de Alzheimer. E assim sendo, estou aprendendo a arte de perder todos os dias. Perdendo meus modos, perdendo objetos, perdendo sono e, acima de tudo, perdendo memórias.

Toda a minha vida eu acumulei lembranças. Elas se tornaram meus bens mais preciosos. A noite que conheci meu marido, a primeira vez que segurei meu livro em minhas mãos, ter filhos, fazer amigos, viajar pelo mundo. Tudo que acumulei na vida, tudo que trabalhei tanto para conquistar, agora tudo isso está sendo levado embora. Como podem imaginar, ou como vocês sabem, isso é o inferno. Mas fica pior.

Quem nos leva a sério quando estamos tão diferentes do que éramos? Nosso comportamento estranho e fala confusa mudam a percepção que os outros têm de nós e a nossa percepção de nós mesmos. Tornamo-nos ridículos. Incapazes. Cômicos. Mas isso não é quem nós somos. Isso é a nossa doença. E como qualquer doença, tem uma causa, uma progressão, e pode ter uma cura. Meu maior desejo é que meus filhos, nossos filhos e a próxima geração não tenha que enfrentar o que estou enfrentando. Mas, por enquanto, ainda estou viva. Eu sei que estou viva. Tenho pessoas que amo profundamente, Tenho coisas que quero fazer com a minha vida. Eu fui dura comigo mesma por não ser capaz de lembrar das coisas. Mas ainda tenho momentos de pura felicidade e alegria. E, por favor, não pensem que estou sofrendo. Não estou sofrendo. Estou lutando. Lutando para fazer parte das coisas, para continuar conectada com quem eu fui um dia.

'Então, viva o momento', é o que digo para mim mesma. É tudo que posso fazer. Viver o momento e não me culpar tanto por dominar a arte de perder. Uma coisa que vou tentar guardar é a memória de falar aqui hoje. Irá embora, sei que irá. Talvez possa desaparecer amanhã. Mas significa muito estar falando aqui hoje. Como meu antigo eu, ambicioso, que era tão fascinado em comunicação. Obrigada por essa oportunidade. Significa muito para mim." 3

Esse comovente discurso remete ao cenário alarmante do aumento significativo da incidência da doença de Alzheimer nas últimas décadas, sobretudo entre idosos, revelando-se um grande desafio para família, sociedade e Estados, desde a vida pessoal de cada afetado pela doença até as políticas públicas que devem ser formuladas especialmente para pessoas com alguma demência.

Segundo dados da Organização Mundial de Saúde e da Alzheimer 's Disease International, divulgados em 2012, a demência é principal causa de invalidez e dependência entre idosos mundialmente. Estima-se que a

\footnotetext{
${ }^{3}$ STILL ALICE. Direção: Richard Glatzer eWash Westmoreland. Produção: Lynn Appelle, Declan Baldwin, James Brown e outros. Roteiro: Lisa Genoveva, Richard Glatzer eWash Westmoreland. Intépretes: Julianne Moore, Alec Baldwin, Kristen Stewart, Kate Bosworth, Hunter Parrish, Stephen Kunken e outros. New York: Lutzus-Brown; Killer Films; BSM Studio; Big Indie Pictures; Shriver Films, 2014, 1 filme (101 min).
} 
cada ano surgem 7,7 milhões novos casos de demência, dentre os quais o Alzheimer é o mais recorrente. ${ }^{4}$

A falta de conscientização e compreensão das demências resulta, na maioria dos países, em estigmatização, em barreiras para o diagnóstico e o cuidado, atingindo os cuidadores, familiares e a sociedade física, psicológica e economicamente. Por isso, é imprescindível que a demência integre a agenda de saúde pública em todos os países.

Enquanto não se lograr encontrar a cura para esse mal que cresce num ritmo epidêmico, urge buscar novas soluções e mecanismos jurídicos para atender a essa parcela da população afetada pela doença de Alzheimer e assegurar-lhes da melhor maneira possível o direito ao livre desenvolvimento de sua personalidade e o exercício de todas as expressões de vida ${ }^{5}$, ainda que numa condição de extrema vulnerabilidade. $\mathrm{O}$ diagnóstico de Alzheimer não torna as pessoas menos humanas, nem interfere no núcleo duro de sua dignidade, que deve continuar sendo absolutamente considerado e respeitado. Mesmo acometidas com a doença, continuam traçando suas histórias e experiências, lutando e se superando a cada dia. $O$ que as define não são o senso de desorientação, os esquecimentos constantes, a repetição de frases, o comprometimento cognitivo ou a dificuldade para executar atividades cotidianas, mas sim a sua trajetória de vida, o que construíram, seus valores, sonhos e paixões, sua liberdade de decidir por onde seguir enquanto for possível.

Tendo em vista este panorama, é de suma importância destacar o advento da Lei no $13.146 / 15$, mais conhecida por Estatuto da Pessoa com Deficiência ou Lei Brasileira de Inclusão, que traz diversas contribuições para o Direito brasileiro no que toca ao tratamento destinado à pessoa com deficiência física, sensorial, mental ou intelectual. De acordo com o art. $1^{\circ}$ do referido diploma legal, este pretende "assegurar e promover, em condições de igualdade, o exercício dos direitos e liberdades fundamentais por pessoa com deficiência, visando à sua inclusão social e cidadania". Nesta linha, o EPD prevê, em seu art.6 ${ }^{\circ}$, que "a deficiência não afeta a plena capacidade da pessoa", inclusive para o exercício de seus direitos de natureza existencial (casar-se, ter filhos, direito à convivência familiar e comunitária, direito ao planejamento familiar, entre outros).

Tal circunstância, evidentemente, provocou severas mudanças no tradicional regime das incapacidades do Código Civil de 2002, desvinculando as concepções de deficiência e incapacidade. Com a nova redação atribuída pelo EPD aos arts. $3^{\circ}$ e $4^{\circ}$ do Código Civil de 2002, "os que, por enfermidade ou deficiência mental, não tiverem o necessário discernimento para prática dos atos da vida civil" e "os que, mesmo por causa transitória, não puderem exprimir sua vontade" saíram da categoria de absolutamente incapazes, permanecendo apenas os menores de 16 (dezesseis) anos. Serão, então, reputados relativamente incapazes os maiores de 16 (dezesseis) e

\footnotetext{
4 World Health Organization 2012.Dementia: a public health priority, p.4. Disponível em: <http://apps.who.int/iris/bitstream/10665/75263/1/9789241564458_eng.pdf> Acesso em 02/07/2016.
} 
menores de 18 (dezoito) anos, os ébrios habituais e os viciados em tóxicos, os pródigos e aqueles que, por causa transitória ou permanente, não puderem exprimir sua vontade.

A Lei no 13.146/15 surge como fruto de um movimento mundial de inclusão da pessoa com deficiência nas últimas décadas, que culminou na promulgação da Convenção Internacional dos Direitos da Pessoa com Deficiência pela ONU, da qual o Brasil é signatário. A CDPD foi incorporada ao ordenamento jurídico brasileiro pelo Decreto no 6.949/2009, através do rito do art. 5ª $\$ 3^{\circ}$, da Constituição Federal, com status de emenda constitucional, no entanto, só com a instituição do EPD as diretrizes da referida convenção passaram a se concretizar no plano infraconstitucional ${ }^{6}$. A CDPD inseriu os princípios da autonomia e da capacidade das pessoas com deficiência, tornando a colocação da pessoa em regime de curatela como instrumento extraordinário e com alcance restrito a atos de natureza patrimonial e negocial ${ }^{7}$.

O Alzheimer, do ponto de vista da Medicina e da Psiquiatria, é classificado como uma doença mental, assim como as demais demências. Salienta-se que existem distinções na conceituação de deficiências mentais e doenças mentais e que sua diferenciação é importante para fins de promoção de políticas públicas. Sem embargo, este artigo toma como parâmetro uma definição de deficiência em sentido amplo, como um impedimento de longo prazo de natureza física, sensorial, mental ou intelectual que, em conjunto com uma ou mais barreiras, obstrui a participação plena e efetiva da pessoa na sociedade em igualdade de condições com as demais, conforme dispõe o art. 2० do EPD.

A Lei Brasileira de Inclusão (LBI) ou Estatuto da Pessoa com Deficiência (EPD) atendeu aos anseios da maior parte da doutrina e, assim, tratou de separar a esfera existencial da esfera patrimonial da pessoa com deficiência. A proposta deste trabalho cinge-se à análise da esfera existencial da pessoa com deficiência, em especial relacionada à sua inserção na sociedade civil, tratando dos institutos da curatela e da tomada de decisão apoiada. O cuidado se coloca como central no debate e na discussão do tema, especialmente em virtude do reconhecimento da especial condição da pessoa com deficiência e seu tratamento inclusivo. Buscar-se-á também fazer uma análise interdisciplinar, principalmente na perspectiva de se reconhecer o modelo social do tratamento jurídico das questões que envolvem a pessoa com deficiência, e não o modelo médico.

O artigo buscará tratar do tema da capacidade civil consoante as inovações legislativas operadas pela Lei

\footnotetext{
${ }^{5}$ TEIXEIRA, Ana Carolina Brochado. Deficiência Psíquica e Curatela: Reflexões Sobre o Viés da Autonomia Privada. Revista Brasileira de Direito das Famílias e Sucessões, Belo Horizonte, v. 7, 2009, p. 77.

${ }^{6}$ A principal contribuição do EPD é regulamentar no plano infraconstitucional as normas da Convenção sobre os Direitos das Pessoas com Deficiência, apresentando contornos próprios de aplicação de algumas normas convencionais à realidade da ordem jurídica brasileira (LEITE, Flávia Piva Almeida; RIBEIRO, Lauro Luiz Gomes; COSTA FILHO, Waldir Macieira (coords.). Comentários ao Estatuto da Pessoa com Deficiência. São Paulo: Saraiva, 2016, p. 42).

${ }^{7}$ COSTA FILHO, Waldir Macieira da. Reflexões sobre a Lei n. 13.146, a concepção da deficiência e capacidade legal e tomada de decisão apoiada. Revista do Ministério Público do Estado do Pará. v. 9, n. 9. Belém: Ministério Público do Estado do Pará, 2016, p. 254.
} 
no 13.146/2015 no que toca à releitura do regime das incapacidades, à ressignificação do instituto da curatela e à introdução do procedimento da tomada de decisão apoiada no sistema jurídico pátrio. Para tanto, a metodologia utilizada para elaboração do trabalho foi a teórico-conceitual, com análise crítica e escorada em pesquisa doutrinária, jurisprudencial e legal sobre o tema. Vale ainda frisar a generosa interdependência do texto elaborado com outros campos do conhecimento: Medicina, Psicologia, Sociologia e Serviço Social.

\section{PERSONALIDADE E CAPACIDADE}

Nas últimas décadas, o Direito Civil vem sofrendo profundas transformações, afastando-se cada vez mais da perspectiva patrimonialista- individualista do Código Civil de $1916^{8}$ para buscar novos paradigmas sempre iluminados pelo conjunto de princípios e valores constantes da Constituição Federal de 1988, em especial o axioma da dignidade da pessoa humana e da incidência das normas dos direitos e garantias fundamentais. Pode-se dizer que o Direito Civil brasileiro foi reformado mediante a "articulação entre a eficácia normativa dos princípios e a abertura democrática do sistema jurídico através da aplicação dos princípios constitucionais" ${ }^{\prime}$, cujo papel foi reconhecido nas relações do Direito Privado.

As normas constitucionais estão localizadas no topo do sistema jurídico brasileiro, desempenhando funções de interpretação, integração e de construção das demais normas do ordenamento. Pode-se dizer, portanto, que a Carta Magna alavancou uma autêntica reestruturação da dogmática jurídica, a partir da afirmação da cidadania como elemento propulsor. ${ }^{10}$

A pessoa natural é o ser humano e a sua dignidade é o fundamento principal da República Federativa do Brasil e pilar básico do ordenamento jurídico brasileiro, consubstanciado no art. 1º III, da CF. A pessoa humana é o "ponto de partida e o alvo, direto ou indireto, de todas as construções jurídicas" ${ }^{11}$, sendo a Ciência Jurídica elaborada pelo homem e para o homem. Logo, toda pessoa natural é dotada de personalidade jurídica, adquirindo direitos e contraindo deveres. Daí a cláusula geral de proteção e tutela da pessoa humana, irradiada pelo texto constitucional, conferir à pessoa uma proteção jurídica compatível com sua estrutura biopsicológica.

Neste processo de constitucionalização do Direito Civil, Célia Barbosa Abreu comenta que a visão estrutural da personalidade tornou-se insuficiente, já que ganhou patamar de valor fundamental no ordenamento

\footnotetext{
${ }^{8}$ Para uma visão do período histórico que ensejou a promulgação do Código Civil de 1916 é sempre recomendável a leitura de GOMES, Orlando. Raízes históricas e sociológicas do Código Civil brasileiro. São Paulo: Martins Fontes, 2003.

${ }^{9}$ MORAES, Maria Celina Bodin de. A caminho do Direito Civil Constitucional. Revista de Direito Civil. São Paulo: RT, n.65, jul./set. 1993, p.24.

${ }^{10}$ ROSENVALD, Nelson. FARIAS, Cristiano Chaves de. Curso de Direito Civil:parte Geral e LINDB. Salvador: Ed. JusPodivm, 2016, p. 61.

${ }^{11}$ NADER, Paulo. Curso de Direito Civil: Parte Geral. Rio de Janeiro: Forense, 2003, p. 181.
} 
jurídico pátrio. São dois seus significados doravante: o antigo, de qualidade conferida pela ordem jurídica a todas as pessoas para integrarem os pólos das relações jurídicas; e o de valor prioritário em meio ao sistema jurídico. ${ }^{12}$

É de suma importância ressaltar que a pessoa natural não pode ser definida tão somente como aquela naturalmente concebida, considerando a existência de técnicas de reprodução assistida, como a inseminação artificial e a fertilização in vitro, alcançadas pelo avanço da medicina e da biotecnologia na contemporaneidade. Portanto, não importa se a concepção é natural ou artificial para fins de caracterização da pessoa natural. A personalidade pode ser conceituada como a soma de caracteres corpóreos e incorpóreos da pessoal natural ou jurídica, isto é, a reunião de aptidões da pessoa. Nesse sentido, a personalidade é compreendida como aquilo que a pessoa é, tanto no plano corpóreo quanto no social. ${ }^{13}$ Conforme o art. 20 do Código Civil de 2002, a personalidade jurídica plena começa com o nascimento com vida. Tal preceito significa que toda e qualquer pessoa natural possui invariavelmente personalidade jurídica, sendo um sujeito de direitos e podendo titularizar relações jurídicas.

O citado artigo coloca a salvo, desde a concepção, os direitos do nascituro, aquele concebido que ainda não nasceu com vida. No entanto, a interpretação desse dispositivo legal gera dúvida sobre se o nascituro poderá ser considerado pessoa, se teria personalidade. Da tentativa de discernir a mens legis do art. $2^{\circ}$, CC, surge uma controvérsia doutrinária entre natalistas e concepcionistas. Os primeiros entendem que a personalidade inicia-se com o nascimento com vida, porque esta seria a intenção literal do legislador, enquanto os segundos sustentam a tese de que o nascituro dispõe dos direitos da personalidade desde a concepção e, em razão disso, já adquire a personalidade jurídica, tendo em vista que "a lei coloca a salvo, desde a concepção, os direitos do nascituro", não obstante seus direitos patrimoniais fiquem condicionados ao nascimento com vida.

Como já dizia a sentença de Hermogeniano - Omneius hominum causa constitutum est ${ }^{14}$ - na obra Digesto, direitos somente se vinculam a pessoas e não a coisas. Deduz-se, por interpretação lógica, que o Código Civil adota a teoria concepcionista e considera o nascituro pessoa humana.

Importante lembrar que a personalidade não depende da consciência ou da vontade do indivíduo. A criança, ainda que recém-nascida, a pessoa com deficiência mental gravíssima ou a pessoa em coma, a despeito da ausência de conhecimento da realidade, ou a falta de reação psíquica, é uma pessoa, logo, dotada de personalidade, qualidade indissociável do ser humano dentro da ordem jurídica que não decorre do preenchimento de qualquer requisito psíquico ou intelectual.

\footnotetext{
${ }^{12}$ ABREU, Célia Barbosa. Curatela: uma Proposta de Leitura Constitucional do Artigo 1.772 do Código Civil Brasileiro. Revista Brasileira de Direito das Famílias e Sucessões, Belo Horizonte, v. 7, 2009, p.96.

${ }^{13}$ TARTUCE, Flávio. Direito Civil, v.1: Lei de Introdução e Parte Geral. 12a ed. rev., atual. eampl. Rio de Janeiro: Forense, 2016, p. 118.

${ }^{14}$ Digesto, Livro I, tít. V, fr. 1: "Todo direito constitui-se em beneficio dos homens."
} 
Nesta esteira de raciocínio, surge o conceito de capacidade, medida da personalidade para prática de determinados atos da vida civil. Dessa forma, qualquer pessoa humana pode ser titular de direitos e obrigações, entre outras posições jurídicas, contudo nem toda pessoa praticará atos da vida civil pessoalmente - apenas aqueles que possuem plena capacidade.

A ordem jurídica brasileira reconhece ao indivíduo a capacidade para a aquisição dos direitos e para exercê-los por si mesmo ou por intermédio de um terceiro através das técnicas de representação e assistência. Logo, personalidade e capacidade complementam-se: a personalidade somente se concretiza com a capacidade jurídica, que se amolda ao conteúdo da personalidade. No sentido genérico, não existem restrições à capacidade, vez que todo direito está apto a materializar-se. Quem tem aptidão para adquirir direitos deve ser hábil a gozá-los e exercê-los, pessoalmente ou por via da representação ou assistência, podendo a inércia do sujeito, no que toca ao seu direito, ser uma forma de fruição, inclusive.

A capacidade é o instrumento pelo qual se realiza a personalidade, essência do ser humano. Afirma Silmara Chinellato que "a personalidade é um quid (substância, essência) e a capacidade é o quantum". ${ }^{15}$ Portanto, a privação total de capacidade implica a frustração da personalidade: se o homem, sujeito de direitos, não tivesse capacidade genérica para adquiri-los, o resultado seria seu aniquilamento do mundo jurídico. Porque toda pessoa tem personalidade jurídica, dispõe outrossim da faculdade abstrata de gozar de seus direitos.

\section{CAPACIDADE DE DIREITO E CAPACIDADE DE FATO}

Faz-se necessário distinguir a capacidade de direito, de gozo ou de aquisição e a capacidade de fato, de exercício ou de ação. A capacidade de direito é aquela derivada da própria condição de pessoa humana e, por isso, confunde-se facilmente com a concepção de personalidade. Consiste na aptidão genérica reconhecida a todas as pessoas humanas e estendida aos agrupamentos morais, que podem ser titulares de direitos e obrigações. Assim, a capacidade de direito é fundamental, tendo em vista que contém potencialmente todos os direitos de que o homem pode ser sujeito e não pode ser recusada ao indivíduo, sob pena de retirar dele os predicados da personalidade.

Já a capacidade de fato resume-se à aptidão de exercer pessoalmente os atos da vida civil e, por isso, possibilita variação e gradação, abrangendo desde os plenamente capazes aos relativas ou absolutamente incapazes. É exatamente na capacidade de fato que se aplica o regime das incapacidades, pois não é possível nivelar a capacidade de direito, por ser absoluta como a personalidade.

\footnotetext{
${ }^{15}$ CHINELLATO, Silmara Juny (coord). Código Civil interpretado. 3a ed. Org. Costa Machado. São Paulo: Manole, 2010, p.27.
} 
Logo, a capacidade de fato, ou seja, "a possibilidade de praticar atos com efeitos jurídicos adquirindo, modificando ou extinguindo relações jurídicas" ${ }^{\prime 6}$, advém do preenchimento de requisitos biológicos e legais e pode sofrer limitação proveniente de idade ou estado de saúde da pessoa. Às vezes faltam requisitos materiais para que as pessoas exerçam pessoal e diretamente seus direitos, condicionando seu exercício à atuação de terceiros que os assistam ou representem de acordo com seu grau de incapacidade.

Sob a ótica de Célia Barbosa Abreu, "a capacidade de direito é simples condição de gozo, uma posição estática, ao passo que a capacidade de exercício denota uma atividade dinâmica, compreendendo o poder de pôr em movimento os direitos" ${ }^{17}$.

Por conseguinte, toda pessoa tem a faculdade de adquirir direitos, mas nem toda pessoa tem o poder de usá-los por si mesmo ou transmiti-los a outrem por ato de vontade. A regra é a capacidade e a incapacidade é exceção; quer dizer, toda pessoa dispõe de capacidade de aquisição e presume-se a capacidade de ação; somente por exceção expressamente derivada da lei é que se nega a capacidade de fato ao indivíduo. Do mesmo modo, ninguém pode renunciar à sua capacidade, reduzir sua capacidade ou declarar-se incapaz, seja de direito ou de fato.

É, ainda, importante a distinção entre capacidade e legitimação ou legitimidade. A legitimação é uma condição especial para celebrar determinado ato ou negócio jurídico; é um requisito específico, legalmente exigido, para a realização de certos atos. É como um plus na capacidade jurídica. A título exemplificativo, cita-se o art. 496, CC, que prevê a anulabilidade da venda de imóvel entre ascendente e descendente sem o consentimento dos demais herdeiros. Neste caso, a concordância dos demais interessados na prática do negócio jurídico é a legitimação imposta pelo ordenamento jurídico, visando proteger o direito à herança.

A legitimidade, por sua vez, diz respeito ao Direito Processual Civil e caracteriza-se como uma das condições da ação. O art. 17 do Código de Processo Civil de 2015, equivalente ao art. $3^{\circ}$ do CPC/73, estabelece que para propor ou contestar ação é preciso ter interesse e legitimidade - seja ela ativa (autor da demanda) ou passiva (réu da demanda).

As distinções aqui destacadas entre capacidade de gozo (ser titular da relação jurídica) e capacidade de exercício (poder praticar o ato pessoalmente) somente se aplicam, na atual fase do Direito Civil, na hipótese do exercício dos direitos patrimoniais. Isso significa que, em relação às situações jurídicas existenciais, essa classificação não mais encontra o mesmo respaldo, como no caso dos direitos da personalidade. Qualquer pessoa - maior ou menor, dotada ou não de capacidade de fato - pode efetivar ou reclamar seus interesses existenciais pessoal e diretamente, sob pena de prejuízo à sua dignidade. Patrocinam essa tese os doutrinadores Joyceanne

\footnotetext{
${ }^{16}$ AMARAL, Francisco. Direito Civil: Introdução. 5a ed. Rio de Janeiro:Renovar, 2003, p. 229.

${ }^{17}$ ABREU, Célia Barbosa. Capacidade Civil, Discernimento e Dignidade do Portador de Transtorno Mental. Revista Brasileira de Direito das Famílias e Sucessões, Belo Horizonte, v. 8, 2009, p.5.
} 
Bezerra de Menezes, Célia Barbosa Abreu, Nelson Rosenvald, Cristiano Chaves e Ana Carolina Brochado Teixeira, como será estudado nos próximos tópicos. ${ }^{18}$

\section{REGIME DAS INCAPACIDADES NUMA PERSPECTIVA CONTEMPORÂNEA}

De forma objetiva, a incapacidade é o reconhecimento da ausência dos requisitos considerados indispensáveis pela lei numa pessoa para que ela coloque em prática seus direitos por si mesma. O direito positivo trata taxativamente das hipóteses de restrição à plena capacidade - casos de absoluta ou relativa incapacidade -, considerando que a limitação ao exercício dos atos da vida civil, seja por idade ou por motivo de saúde, é excepcional.

O incapaz, portanto, requer um tratamento diferenciado na medida em que não apresenta o mesmo quadro de compreensão da vida e dos atos cotidianos das pessoas plenamente capacitadas. É vital observar a regra de que os desiguais devem ser tratados na medida de sua desigualdade, tendo por fundamento a noção de igualdade substancial, para impor efetividade às garantias fundamentais das pessoas incapazes e resguardar sua dignidade em igualdade de condições às pessoas capazes.

Nesse sentido, a proteção jurídica destinada aos incapazes deve ser realizada através da concessão de um conjunto de medidas diferenciadas e não propriamente da retirada da plena capacidade, no caso, a capacidade de agir pessoal e diretamente. Pontua a doutrinadora Célia Barbosa Abreu:

"uma ratio contemporânea do regime jurídico das incapacidades perpassa necessariamente por uma proteção jurídica mais abrangente do cidadão incapaz, pelo enfrentamento das ideias de exclusão e inclusão por uma tutela que não se reduza a resguardar interesse de ordem patrimonial. Assim, o incapaz poderá desenvolver suas potencialidades, superando obstáculos que no passado pareciam intransponíveis e hoje muitas vezes são meramente transitórios". ${ }^{19}$

Resta claro, portanto, que toda a sistemática da denominada interdição reclama uma interpretação restrita, não sendo possível ampliar as hipóteses de incapacidade além das impostas pela lei. Nessa lógica, os arts. $3^{\circ}$ e 4ª ambos do CC, estipularam algumas hipóteses de carência de capacidade jurídica plena, elaborando uma gradação ao exercício da capacidade de fato, isto é, a aptidão de praticar atos da vida civil pessoalmente. Faz-se necessário reiterar que esses diferentes graus de incapacidade não se referem à aptidão para ser titular de relações jurídicas, denominada capacidade de direito.

A incapacidade jurídica, no entanto, não pode ser confundida com a deficiência física ou mental

${ }^{18}$ ROSENVALD, Nelson. FARIAS, Cristiano Chaves de. Curso de Direito Civil: parte Geral e LINDB, op. cit., p. 321.

${ }^{19}$ ABREU, Célia Barbosa. Curatela e interdição civil. Rio de Janeiro: Lumen Juris, 2009, pp. 223-224. 
propriamente dita. Nem todo incapaz o é por apresentar algum tipo de deficiência, pois a limitação em sua capacidade de agir pode estar associada a outro motivo, tal como a idade. Tal qual preconizam os arts. $3^{\circ} \mathrm{e} 4^{\circ}$, do CC, são absolutamente incapazes os menores de 16 (dezesseis) anos e relativamente incapazes aqueles entre 16 (dezesseis) e 18 (dezoito) anos. E, ainda que se considere uma pessoa com deficiência - de ordem mental, intelectual, física ou sensorial, a existência desta não implica obrigatoriamente na incapacidade jurídica do indivíduo. ${ }^{20}$

Certo é que a pessoa humana é valor unitário e fundamental na ordem jurídica, não comportando fragmentações. Isso significa que o ser humano não pode ser visto nem compreendido apenas pelo ângulo da integridade psíquica: a pessoa vai muito além de seu grau de discernimento, é intimidade, privacidade, honra, nome, imagem- é a soma de todas as projeções de sua personalidade. Afora a integridade psíquica, a integridade humana hoje comporta, em sentido amplo, as integridades social, oriunda do direito à inclusão social, e até mesmo ambiental, materializada no direito a um meio ambiente ecologicamente equilibrado, sem o qual restará prejudicado seu direito fundamental à saúde e, consequentemente, seu direito à vida digna. ${ }^{21}$

Nesta perspectiva, cingir a capacidade do indivíduo exclusivamente ao critério do discernimento equivaleria a considerar uma pessoa tomando apenas um dos aspectos de sua personalidade e a colocação da pessoa em regime de curatela, neste caso, poderia configurar medida desproporcional, caracterizando grave violação aos direitos fundamentais e à dignidade da pessoa com deficiência mental.

Por isso, a incapacidade é admitida somente excepcionalmente e resume-se às hipóteses taxativas enunciadas por lei. A rudeza, o analfabetismo, o encarceramento prisional e a senectude, por exemplo, não ensejam o reconhecimento de incapacidade jurídica.

O regime das incapacidades, adotado pela lei civil brasileira, divide os absolutamente incapazes dos relativamente incapazes. Os absolutamente incapazes são aqueles que não possuem qualquer capacidade de agir, sendo irrelevante, do ponto de vista jurídico, sua manifestação de vontade. Embora sejam eles os titulares das relações jurídicas, dependem de terceiros que os representem e pratiquem os atos da vida civil em seu nome. É o caso do menor impúbere representado por seus genitores. Por sua vez, os relativamente incapazes podem praticar

\footnotetext{
${ }^{20} \mathrm{~A}$ título ilustrativo, merecem destaque alguns casos concretos de pessoas que, apesar de apresentarem alguma modalidade de deficiência, superaram dificuldades e traçaram histórias de vida admiráveis, revelando a insuficiência do critério do discernimento como único formador da capacidade jurídica. São eles: "o matemático John Forbes Nash Junior, que teve sua trajetória reproduzida no filme Uma mente brilhante. Ele, apesar de esquizofrênico, com sintomas paranoicos, delírios, alucinações, bem como o fato de ter sido submetido a tratamentos radicais e internado algumas vezes, recebeu o Prêmio Nobel de Economia de 1994", dentre vários outros. Outro célebre caso é o de Chisty Brown, que nasceu com paralisia cerebral, mantendo apenas o movimento do pé esquerdo e, contra todas as expectativas, logrou, no decorrer de sua vida, tornar-se escritor e artista plástico. Ainda, "casos clássicos da psiquiatria, como os do juiz Schereber e do filósofo Louis Althusser, tantas vezes lembrados por doutrinadores pátrios para sustentar a necessidade de um novo tratamento para os temas: interdição e curatela". ABREU, Célia Barbosa. Capacidade Civil, Discernimento e Dignidade do Portador de Transtorno Mental, op.cit., pp. 12-13.
} 
os atos da vida civil, sob condição de que haja assistência, ressalvados alguns atos para os quais podem agir sozinhos. A vontade do assistido não é substituída pela do assistente, como ocorre na técnica da representação, mas devem ser manifestadas conjuntamente para que o ato ou negócio jurídico seja reputado válido.

A realização de um ato pelo incapaz, sem a necessária representação ou assistência, acarretará em sua invalidade, absoluta ou relativa, de acordo com o tipo de incapacidade: os atos praticados pelos absolutamente incapazes serão considerados nulos, não produzindo qualquer efeito jurídico (eficácia ex tunc); enquanto os atos executados pelos relativamente incapazes serão anuláveis, produzindo efeitos até que the sobrevenha uma decisão judicial reconhecendo sua invalidade (eficácia ex nunc).

Oportuno observar que alguns atos, relacionados na lei civil, podem ser praticados pelos relativamente incapazes sem assistência, como se casar (nesta hipótese necessitando de autorização dos pais ou representantes), elaborar testamento, servir como testemunha de atos e negócios jurídicos, requerer registro de seu nascimento, ser empresário (com autorização), ser eleitor, ser mandatário ad negotia (mandato extrajudicial). ${ }^{22}$

O Código Civil de 2002, em sua redação original, determinava três figuras jurídicas como absolutamente capazes, em seu art. $3^{\circ}$ : a) os menores de 16 (dezesseis) anos; b) os que, por enfermidade ou deficiência mental, não tivessem o necessário discernimento para a prática desses atos; c) os que, mesmo por causa transitória, não pudessem exprimir sua vontade. Em seu art. $4^{\circ}$, previa os relativamente incapazes a certos atos ou à maneira de os exercer: a) os maiores de 16 (dezesseis) e menores de 18 (dezoito) anos; b) os ébrios habituais, os viciados em tóxicos, e os que, por deficiência mental, tivessem o discernimento reduzido; c) os excepcionais, sem desenvolvimento mental completo; d) os pródigos.

A Lei no $13.146 / 15$, alterou expressivamente o rol das pessoas reputadas incapazes do Código Civil. O mencionado diploma legal revogou os incisos II e III do art. $3^{\circ}$, do CC, preservando apenas os menores impúberes como absolutamente incapazes, bem como modificou a redação dos incisos II e III do art. 4º, do CC, mantendo como relativamente incapazes os maiores de 16 (dezesseis) e menores de 18 (dezoito) anos, os ébrios habituais e viciados em tóxicos, os pródigos e aqueles que, por causa permanente ou transitória, não puderem exprimir sua vontade.

A rigor, o EPD transferiu a hipótese da impossibilidade de expressão da vontade por causa transitória ou permanente, anteriormente ensejadora de incapacidade absoluta, para a lista das causas de incapacidade relativa, além de revogar as demais hipóteses de incapacidade decorrentes da existência de uma deficiência mental. Destarte, não mais se cogita incapacidade jurídica - relativa ou absoluta - derivada de deficiência física, sensorial, intelectual ou mental, por si só. O EPD preocupa-se em assinalar, no caput do seu art. 6º que a deficiência - seja de

\footnotetext{
${ }^{21}$ ABREU, Célia Barbosa. Capacidade Civil, Discernimento e Dignidade do Portador de Transtorno Mental, op.cit., p.12.

${ }^{22}$ TARTUCE, Flávio. Direito Civil,v.1: Lei de Introdução e Parte Geral, op. cit., p. 134.
} 
qual ordem for- não afeta a plena capacidade civil da pessoa, inclusive e sobretudo para realizar seus interesses existenciais, tais quais casar ou constituir união estável, exercer direitos sexuais e reprodutivos ou exercer o direito à família, à convivência familiar e comunitária, entre outros.

A radical mudança dos textos dos arts. $3^{\circ}$ e $4^{\circ}$, do CC, somada à redação do caput do art. $6^{\circ}$ do EPD, provocaram uma série de inovações no regime das incapacidades, repercutindo diretamente em vários outros temas do Direito Civil, tais como o direito de empresa, prescrição e decadência, invalidade dos negócios jurídicos, curatela, responsabilidade civil, sucessões (testamento).

Na perspectiva de Nelson Rosenvald, ao contrário do que dispunha a redação original do Código Civil, que permitia a retirada da plena capacidade jurídica pelo fato da pessoa apresentar transtorno mental e consequente comprometimento do grau de discernimento, o direito constitucional à dignidade, à igualdade e à não discriminação trazem a reboque o direito à singularidade, que é exatamente o direito de ser diferente. ${ }^{23}$

Dessa forma, o EPD busca harmonizar o regime das incapacidades com o conjunto de axiomas constitucionais, razão pela qual a negativa de plena capacidade jurídica a alguém só se justifica na tutela de sua própria dignidade, devendo o juiz, caso a caso, averiguar o grau de incapacidade pelos efeitos existenciais e não pelas consequências econômicas e sociais.

Por conseguinte, a Lei no 13.146/15 mitigou, mas não aniquilou, o regime das incapacidades, tal como tratado no Código Civil, apenas adequando-a ao conjunto de regras e princípios da Constituição da República de 1988 e da Convenção das Nações Unidas dos Direitos da Pessoa com Deficiência (CDPD).

\section{INCORPORAÇÃO DA CONVENÇÃO INTERNACIONAL DOS DIREITOS DA PESSOA COM DEFICIÊNCIA}

A Convenção de Direitos da Pessoa com Deficiência foi aprovada pelo Decreto Legislativo no 186, de 09 de julho de 2008, e promulgada pelo Decreto no 6.949, de 25 de agosto de 2009, sendo incorporada ao ordenamento jurídico pátrio pelo rito do art. $5^{\circ}, \$ 3^{\circ}$, da CF (aprovação em cada casa do Congresso Nacional, em dois turnos, pelo quórum de três quintos dos votos de seus respectivos membros), isto é, com equivalência de norma constitucional.

Trata-se do primeiro tratado do sistema universal de direitos humanos do século XXI incorporado pelo Direito brasileiro, cujos princípios basilares são o "in dubio pro capacitas" e a "intervenção mínima”. Nesse sentido, promove uma transformação no regime das incapacidades e no modelo de direito protetivo pautado na

${ }^{23}$ ROSENVALD, Nelson. FARIAS, Cristiano Chaves de. Curso de Direito Civil: parte Geral e LINDB, op. cit., p. 329. 
substituição de vontades. ${ }^{24}$

A referida Convenção internacional introduz uma nova concepção, aberta e social, das pessoas com deficiência em seu art. $1^{\circ}$ : são "aquelas que têm impedimentos de longo prazo de natureza física, mental, intelectual ou sensorial, os quais, em interação com diversas barreiras, podem obstruir sua participação plena e efetiva na sociedade em igualdades de condições com as demais pessoas".

Infere-se, portanto, que a inaptidão não está na falta de um membro, na audição reduzida ou na existência de um transtorno mental, ou seja, não está na deficiência em si, mas nos obstáculos encontrados pelas pessoas com deficiência para efetivamente se integrarem na sociedade. Daí dizer que a CDPD filiou-se ao modelo social, em contraposição ao modelo médico, marcado pelo enquadramento das pessoas que possuem algum tipo de inabilidade em categorias de deficiência de acordo com a classificação científica: mental, intelectual, física ou sensorial (auditiva e visual).

O propósito da Convenção, enunciado em seu art. $1^{\circ}$, é o de "promover, proteger e assegurar o exercício pleno e equitativo de todos os direitos humanos e liberdades fundamentais por todas as pessoas com deficiência e promover o respeito pela sua dignidade inerente". O legislador internacional preocupou-se mais com a garantia de que pessoas com deficiência possam gozar dos direitos humanos e de sua liberdade fundamental do que propriamente em instituir novos direitos. A técnica empregada foi adotar como parâmetro as condiçóes de igualdade, inclusive considerando a redação da segunda parte do art. $1^{\circ}$ que traz a definição de "pessoas com deficiência", ratificando a ideia de que barreiras sociais podem prejudicar este grupo na participação na sociedade em condição de igualdade com as demais pessoas. ${ }^{25}$

Conclui-se que, para o legislador internacional, quanto mais se assegura a igualdade de condições entre as pessoas com deficiência e as demais pessoas, maior será a concretização da dignidade do primeiro grupo e, consequentemente, o livre exercício de suas liberdades fundamentais. A igualdade pressupõe respeito às diferenças pessoais, não significando o nivelamento de personalidades individuais, ou seja, a efetiva e substancial igualdade manifesta-se exatamente levando em conta as distintas peculiaridades de cada pessoa.

De forma resumida, a CDPD busca a superação de barreiras externas de modo a preparar a sociedade para o acolhimento e integração das pessoas com deficiência, ao administrar suas diferenças e semear a capacidade

\footnotetext{
${ }^{24}$ MENEZES, Joyceane Bezerra de. O direito protetivo no Brasil após a convenção sobre a proteção da pessoa com deficiência: impactos do novo CPC e do Estatuto da Pessoa com Deficiência. Civilistica.com. Rio de Janeiro, a. 4, n. 1, jan.- jun./2015, p.5. Disponível em:<http://civilistica.com/wp-content/uploads/2016/01/Menezes-civilistica.com-a.4.n.1.2015.pdf> Acesso em 10.04.2016.

${ }^{25}$ RESENDE, Ana Paula Crosara; VITAL, Flávia Maria de Paiva (coords). A Convenção sobre Direitos das Pessoas com Deficiencia comentada. Brasília: Secretaria Especial dos Direitos Humanos, 2008. Disponível em: $<$ http://www.governoeletronico.gov.br/documentos-earquivos/A\%20Convencao\%20sobre\%20os\%20Direitos\%20das\%20Pessoas\%20com\%20Deficiencia\%20Comentada.pdf>. Acesso em 03.09.2016.
} 
de conviver com a diversidade sem se sentir ameaçada por ela. O art. 12, da CDPD, ao cuidar do direito de igualdade perante a lei, reforça a capacidade legal dessas pessoas para todas as questões da vida, em igualdade de condições com as demais, pretendendo lhes endossar "a possibilidade de condução dos próprios interesses, no exercício de sua capacidade criativa e de sua expressão volitiva, fruto da autonomia que as qualifica na sua humanidade". ${ }^{26}$

Nesse sentido, a Convenção de Direitos da Pessoa com Deficiência estipulou que os Estados Partes devem viabilizar mecanismos de apoio e salvaguardas, quando necessárias, para o exercício pleno da capacidade legal das pessoas com deficiência. Apesar de não determinar taxativamente quais devem ser os instrumentos de apoio, define as salvaguardas como aquelas cautelas ou medidas inclinadas a prevenir abusos, excessos ou ilegalidades que possam ser originados pelo uso indevido de mecanismos de apoio, em consonância com o Direito Internacional dos Direitos Humanos.

Cada Estado é soberano para fixar os métodos de apoio que julgar apropriados e úteis ao exercício dos direitos pelas pessoas com deficiência, sempre em atenção às suas vontades e preferências. Esse apoio deve ser adequado às circunstâncias em que a pessoa se encontra, aplicado pelo período mais curto possível e submetido à revisão regular por uma autoridade ou órgão judiciário competente, independente e imparcial. Assim, as salvaguardas deverão ser proporcionais ao grau em que tais mecanismos de apoio afetarem os direitos e interesses da pessoa.

No Brasil, até janeiro de 2016, a curatela foi o principal método de apoio; no entanto, com a entrada em vigor do Estatuto da Pessoa com Deficiência, foi estabelecida a tomada de decisão apoiada (TDA), modificando significativamente o Código Civil de 2002.

Além da capacidade civil, a CDPD destacou outros assuntos diretamente associados ao Direito Civil: o direito das pessoas com deficiência à integridade psicofísica (art. 17); à liberdade de locomoção e à nacionalidade (art. 18); à vida independente e à inclusão na comunidade, permitindo que elas escolham o local de sua residência e com quem desejam morar de modo que não sejam compelidas a viver em determinado tipo de moradia (art. 19); à ampla mobilidade (art. 20); à liberdade de expressão e opinião (art. 21); à privacidade (art. 22); o direito à constituição e proteção da família (art. 23), impondo aos Estados o dever de assegurar à pessoa com deficiência a faculdade de exercer o poder familiar, a guarda, a custódia, a curatela e pleitear a adoção de crianças, observado sempre o melhor interesse destas.

A contribuição cardeal da Convenção está precisamente no reconhecimento da autonomia e da capacidade das pessoas com deficiência, em igualdade de condições com os outros, como requisitos de sua

\footnotetext{
${ }^{26}$ MENEZES, Joyceanne Bezerra de. O direito protetivo no Brasil após a convenção sobre a proteção da pessoa com deficiência: impactos do novo CPC e do Estatuto da Pessoa com Deficiência, op. cit., p.6.
} 
dignidade e de sua participação na vida social, familiar e política. A autonomia ou a capacidade de autodeterminação, fundamento material da capacidade de agir, traduz-se numa necessidade humana da qual procedem vários direitos.

Maria Celina Bodin de Moraes sintetiza o debate filosófico a respeito da autonomia:

"Aristóteles, Epicuro, Santo Agostinho, Descartes, Kant, Sartre, Habermas, todos os grandes pensadores da Antiguidade aos nossos dias, constataram ser infrutífero discorrer sobre a vida humana sem examinar justamente aquilo que a faz humana, e como tal única, individual e singular: o poder sobre si mesmo."27

Todos têm, em menor ou maior medida, capacidade de querer e de se autodeterminar. O discernimento é considerado a baliza que orienta o exercício dessa capacidade, especialmente quando as escolhas realizadas têm efeitos jurídicos sobre a esfera pessoal ou de terceiros. $\mathrm{O}$ foco, todavia, não está no diagnóstico médico de uma deficiência psíquica ou intelectual per si, mas no discernimento necessário.

Interessa ao Direito a capacidade para prática de atos que tenham o condão de reverberar na esfera jurídica do agente ou de terceiros, recebendo um tratamento especial sob o título de "capacidade jurídica". O Direito Civil, por exemplo, impõe que as partes tenham capacidade jurídica para celebração de negócios jurídicos, sobretudo os de natureza empresarial e de índole patrimonial/econômico. Já no que tange aos fatos jurídicos ou atos-fatos jurídicos, não há que se falar de incapacidades, pois neste âmbito não há exigência de vontade ou discernimento.

A proposta da CDPD é a de apostar na autonomia da pessoa com deficiência, em igualdade de condições com os indivíduos que não apresentam nenhum tipo de deficiência, afirmando sua condição e capacidade para decidir assuntos importantes para as suas vidas sem a interferência, a priori, de terceiros no processo decisório. Se, a despeito de eventual limitação física, psíquica ou intelectual duradoura, preservar o discernimento necessário para prática de um ato civil específico e for apto a exprimir sua vontade, não precisará ser representada ou assistida por terceiros para o exercício de seus direitos e deveres.

No campo do Direito Civil, praticam-se atos de cunho patrimonial, de cunho existencial e aqueles que têm natureza mista (existencial e patrimonial). A título exemplificativo, as relações jurídicas obrigacionais, por vezes, traduzidas em contratos ou as que envolvem direitos reais, tais quais a propriedade, o usufruto ou as servidões, têm natureza eminentemente patrimonial enquanto o casamento, a disposição sobre o próprio corpo, a escolha de um tratamento médico, o reconhecimento de um filho, a liberdade religiosa e profissional, a diretiva antecipada de vontade, a nomeação de um tutor ou curador são atos concernentes à seara existencial da pessoa humana. O testamento (disposição de última vontade), bem como os pactos antenupciais, a administração dos

\footnotetext{
${ }^{27}$ MORAES, Maria Celina Bodin de. Na medida da pessoa humana. Estudos de direito civil-constitucional. Rio de Janeiro: Renovar, 2010, p. 183.
} 
bens dos filhos e os alimentos englobam interesses patrimoniais e extrapatrimoniais da vida das pessoas, pois estão associados às relações endofamiliares.

A depender do tipo de ato civil, exige-se certo nível de compreensão. Evidente que o discernimento demandado para a realização de atos civis de caráter patrimonial não é o mesmo que se requer para os atos existenciais, vez que se situam em esferas distintas. Os primeiros abrangem informações mais técnicas e jurídicas, menos subjetivas, ao passo que os segundos estão mais ligados aos vínculos pessoais, às preferências e às circunstâncias típicas da personalidade de cada um, ou seja, o seu modo único de ser. ${ }^{28}$

Deduz-se que uma pessoa com déficit psíquico ou intelectual tenha mais dificuldade de entender as consequências advindas de um contrato de compra e venda ou a dinâmica da administração societária, fazendo-se necessária a atuação de um curador ou o apoio de alguém. Em contrapartida, essa mesma pessoa pode agregar condições de compreender e decidir sobre temas referentes à sua vida pessoal e afetiva, tais como onde deseja residir, com quem pretende morar, com quem deseja se relacionar ou quem lhe inspira confiança para ser seu apoiador/curador.

Enquanto os negócios jurídicos patrimoniais repercutem na esfera disponível do indivíduo, os atos civis existenciais atingem interesses indisponíveis, intransmissíveis e, geralmente, irrenunciáveis, não sendo passíveis de representação (substituição de vontade) na maior parte das vezes, pois a pessoa que titulariza o direito deve praticar pessoalmente o ato. Devido à contiguidade entre os interesses existenciais e os princípios da dignidade da pessoa humana, da integridade psicofísica, da igualdade e do livre desenvolvimento da personalidade, é que se intensifica a proteção constitucional voltada à autonomia decisória do sujeito nesta seara.

Estimula-se que a pessoa, ainda que se utilize de mecanismos de apoio ou cuidado adicional por terceiros ou pelo poder público em razão de uma restrição psíquica ou intelectual, decida sobre as situações existenciais de sua vida, pois isso contribui para o delineamento de sua própria identidade.

\section{MUDANÇAS NA LEGISLAÇÃO BRASILEIRA}

\section{Capacidade civil sob a ótica do Estatuto da Pessoa com Deficiência}

No panorama atual da legislação brasileira, vale a pena proceder à análise do texto da Convenção dos Direitos da Pessoa com Deficiência, do Código de Processo Civil (Lei no 13.105, de 16 de março de 2015), cuja vigência iniciou-se no dia 16 de março de 2016, e do Estatuto da Pessoa com Deficiência (Lei no 13.146, de 6 de

\footnotetext{
${ }^{28}$ MENEZES, Joyceane Bezerra de. O direito protetivo no Brasil após a convenção sobre a proteção da pessoa com deficiência: impactos do novo CPC e do Estatuto da Pessoa com Deficiência, op. cit., p.8.
} 
julho de 2015), que entrou em vigor em 03 de janeiro de 2016.

Ao CPC/15, no que tange ao procedimento da colocação em regime de curatela (arts. 747 a 758), coube seguir uma disciplina mais aberta, buscando cercear a capacidade do interdito apenas aos precisos limites de sua necessidade e em respeito aos seus direitos fundamentais. O CPC revogou os arts. 1768 e 1773 do Código Civil de 2002 e trouxe algumas novidades. No entanto, esse diploma legal não era suficiente para cuidar de todas as mudanças trazidas pela Convenção de Nova Iorque para o ordenamento jurídico brasileiro, tornando-se necessária a elaboração de um estatuto tivesse interferência mais objetiva no plano infraconstitucional.

Então, foi aprovado o Estatuto da Pessoa com Deficiência (EPD), lei que implementou mais efetivamente a ratio da CDPD, instituindo profundas alterações no plano das relações públicas e privadas com o fito de assegurar a inclusão da pessoa com deficiência.

Quando o Estatuto assegura o direito à igualdade e à não discriminação ( $\operatorname{art.} 4^{\circ}$ e ss.), corrobora o teor da CDPD e o tratamento humanista por ela inaugurado. Rompe-se com a ideia de que a pessoa com deficiência é, em algum nível, inferior às demais e de que a capacidade jurídica é critério para conquistar a titularidade dos direitos fundamentais. A evolução destes direitos está justamente em seu alcance a um público cada vez mais amplo, tendencialmente universal. No mundo ocidental, as garantias oferecidas pelo Direito positivo já não se destinam somente a indivíduos determinados, eleitos pelos critérios de identidade, cidadania e capacidade jurídica. ${ }^{29}$

Em seu art. 6º o EPD prevê que a deficiência, seja de qual ordem for, não afetará a plena capacidade civil da pessoa, que poderá casar-se e constituir união estável, exercer direitos sexuais e reprodutivos, exercer o direito de decidir o número de filhos, ter acesso às informações adequadas sobre reprodução e planejamento familiar, conservar a sua fertilidade, exercer o direito à família e à convivência comunitária e exercer o direito à guarda, à tutela, à curatela e à adoção, como adotante ou adotado, em igualdade de oportunidades com as demais pessoas.

A Lei no 13.146/15 revoga expressamente os incisos I, II e III do art. 3º, do CC, de modo que a deficiência deixa de ser um critério hábil para afirmar a incapacidade absoluta do sujeito, permanecendo como absolutamente incapazes para a prática dos atos da vida civil apenas os menores de 16 (dezesseis) anos. Outrossim, altera a redação dos incisos II e III do art. 4o do CC02, passando a reputar como relativamente incapazes a certos atos ou à maneira de os exercer os ébrios habituais e os viciados em tóxico, bem como aqueles que, por causa transitória ou permanente, não puderem exprimir sua vontade, os pródigos e aqueles entre 16 (dezesseis) e 18 (dezoito) anos.

Para Ronald Dworkin, a autonomia é a qualidade que melhor caracteriza o ser humano, pois a pessoa

${ }^{29}$ FERRAJOLI, Luigi. Los fundamentos de los derechos fundamentales. Madrid: Editorial Trotta, 2001, p. 24. 
pode ser protagonista de sua própria história, traçando suas escolhas e assumindo as consequências delas. Nesta esteira de raciocínio, "é sempre melhor reconhecer o direito geral à autonomia e respeitá-lo, em vez de nos reservarmos o direito de interferir na vida das outras pessoas sempre que acreditarmos que tenham cometido um erro" ${ }^{30}$ Pode ser que a pessoa decida contrariamente ao que sabe ser melhor para ela e ainda sim esteja no uso de sua autonomia. Esta é centrada na integridade e não necessariamente no bem-estar da pessoa. Importa, portanto, assegurar que o respeito à capacidade geral de agir possibilite à pessoa conduzir a sua existência de modo íntegro e autêntico em conformidade com o que entende ser importante para si.

É o direito à autonomia, decorrente da dignidade da pessoa humana, que viabiliza a autocriação e o desenvolvimento da personalidade do sujeito, nos limites definidos pelo sistema jurídico. O modo como a sociedade enxerga esse protagonismo para a vida de cada um reflete na forma como a lei trata a questão da autonomia e da tomada de decisões. Se o Estado brasileiro garante à pessoa, indistintamente, a dignidade que a qualifica como humana, não pode recusar efeito jurídico a essa autonomia, exceto nos casos extremos e especificamente explanados, sempre com o objetivo de melhor the tutelar. ${ }^{31} \mathrm{O}$ art. 10, do EPD, dispõe expressamente que "compete ao poder público garantir a dignidade da pessoa com deficiência ao longo de toda vida".

Quando, então, seria possível uma intervenção na sua autonomia? Dependerá do grau de discernimento e da aptidão da pessoa com deficiência de expressar sua vontade. Porém, fundamental ressaltar que a análise desse discernimento e dessa capacidade de expressão é casuística, não podendo ser marcada por critérios objetivos, abstratamente adotados pela lei. A regra geral permanece sendo a capacidade plena de modo que, para retirar ou restringir a capacidade de alguém, a pessoa deve ser avaliada na conjuntura de sua própria vida e sua eventual incapacidade deve ser comprovada por meio do devido processo legal e da atuação de uma equipe multidisciplinar, que avaliará minuciosamente as circunstâncias do caso concreto.

Ademais, o Estatuto reconhece à pessoa com deficiência o direito de não ser submetida a qualquer tipo de tratamento médico, intervenção clínica, cirúrgica ou institucionalização forçada (art. 12). Exige-se que a própria pessoa assine o termo de consentimento prévio, livre e esclarecido para realização do tratamento, intervenção médica ou pesquisa científica. As únicas ressalvas para atendimento sem consentimento, constantes no art. 13, são nas hipóteses de risco de morte e de emergência em saúde, sempre preservados o superior interesse do indivíduo e as salvaguardas legais.

Se o sujeito estiver com dificuldades reais de exercer sua capacidade civil, antes de ter sua autonomia

\footnotetext{
${ }^{30}$ DWORKIN, Ronald. Domínio da vida: aborto, eutanásia e liberdades individuais. São Paulo: Martins Fontes, 2003, p. 317.

${ }^{31}$ MENEZES, Joyceane Bezerra de. O direito protetivo no Brasil após a convenção sobre a proteção da pessoa com deficiência: impactos do novo CPC e do Estatuto da Pessoa com Deficiência, op. cit., p.14.
} 
aniquilada, poderá optar pelo procedimento de tomada de decisão apoiada, medida de apoio mais branda, implantada pelo EPD com o acréscimo do art. 1783-A ao Código Civil de 2002.

Excepcionalmente, constatada a completa ausência de discernimento ou a inaptidão para expressão de vontade, poderá a pessoa com deficiência, observadas as cautelas necessárias e o devido processo legal, ser submetida ao regime de curatela, o que lhe reduz a autonomia, vez que será reputada relativamente incapaz. A curatela passa a ser medida protetiva extraordinária, sempre proporcional às demandas do curatelado e destinada somente aos direitos de natureza patrimonial ou negocial ( $\operatorname{art} .84, \$ 3^{\circ}$ e art.85, capute $\$ 1^{\circ}$ ). Deverá durar o menor tempo possível, tendo o relativamente incapaz direito de que as decisões tomadas em seu nome se proponham a alcançar seus interesses fundamentais $\left(\operatorname{art.} 85, \$ 2^{\circ}\right)$.

A seguir, tratar-se-á da tomada de decisão apoiada.

\section{Tomada de decisão apoiada}

A tomada de decisão apoiada é um mecanismo de apoio ao exercício da capacidade civil, introduzido pela Lei no 13.146/2015, com a adição do art. 1783-A, caput, e onze parágrafos ao texto do CC02. Nos dizeres de Nelson Rosenvald e Cristiano Chaves, a TDA surge como um tertium genus protetivo, junto à curatela e à tutela, destinado à assistência da pessoa com deficiência que preserva sua autonomia e, portanto, a plenitude de sua capacidade civil. ${ }^{32}$ Consiste num modelo protecionista para pessoas plenamente capazes, contudo em situação de vulnerabilidade por conta de uma limitação de ordem física, sensorial, intelectual ou mental, mas sem o viés paternalista.

Esse novo instituto materializa o art. 12.3 do Decreto no 6.949/09 que promulgou a Convenção das Nações Unidas sobre os Direitos das Pessoas com Deficiência ${ }^{33}$, inspirando-se no Código Civil italiano, que prevê

\footnotetext{
${ }^{32}$ ROSENVALD, Nelson. FARIAS, Cristiano Chaves de. Curso de Direito Civil: parte Geral e LINDB, op. cit., pp. 338/339.

${ }^{33}$ Decreto no. 6.949/2009, "Artigo 12- Reconhecimento igual perante a lei:

1.Os Estados Partes reafirmam que as pessoas com deficiência têm o direito de ser reconhecidas em qualquer lugar como pessoas perante a lei.

2.Os Estados Partes reconhecerão que as pessoas com deficiência gozam de capacidade legal em igualdade de condições com as demais pessoas em todos os aspectos da vida.

3.Os Estados Partes tomarão medidas apropriadas para prover o acesso de pessoas com deficiência ao apoio que necessitarem no exercício de sua capacidade legal.

4.Os Estados Partes assegurarão que todas as medidas relativas ao exercício da capacidade legal incluam salvaguardas apropriadas e efetivas para prevenir abusos, em conformidade com o direito internacional dos direitos humanos. Essas salvaguardas assegurarão que as medidas relativas ao exercício da capacidade legal respeitem os direitos, a vontade e as preferências da pessoa, sejam isentas de conflito de interesses e de influência indevida, sejam proporcionais e apropriadas às circunstâncias da pessoa, se apliquem pelo período mais curto possível e sejam submetidas à revisão regular por uma autoridade ou órgão judiciário competente, independente e imparcial. As salvaguardas serão proporcionais ao grau em que tais medidas afetarem os direitos e interesses da pessoa.
} 
em seus arts. 404 a 413 a figura do amministratore di sostegno (administrador de apoio), e no novo Código Civil argentino cujo art. 43 dispõe sobre a proteção de indivíduos juridicamente vulneráveis no exercício de sua capacidade civil.

Certo é que a curatela e a tutela são medidas prioritariamente formatadas para o campo patrimonial, tendentes à proteção de um incapaz. Para se aproximar das diretrizes personalistas vislumbradas pelo movimento Civil-Constitucional no Direito, o Estatuto da Pessoa com Deficiência implementa um modelo inclinado à proteção do plenamente capaz, porém vulnerável em virtude de alguma circunstância pessoal, física, psíquica ou intelectual, qual seja, a TDA. Enquanto a curatela e o regime da incapacidade relativa parecem atender preferencialmente aos interesses da sociedade (isolando os incapazes) e da família (impedindo que seu patrimônio seja dilapidado), em detrimento do próprio curatelado, a tomada de decisão apoiada busca garantir à pessoa com deficiência o direito de decidir de acordo com suas preferências, mas ciente dos efeitos de sua escolha. Por isso, o apoio pode incluir o esclarecimento de fatores circundantes à decisão, a avaliação sobre seus efeitos, além do auxílio na comunicação dessa decisão aos interlocutores.

Cuida-se, portanto, de figura bem mais flexível que a curatela, pois não pretende limitar a capacidade, mas sim funcionar como um remédio personalizado para as necessidades existenciais e patrimoniais da pessoa, no qual prevalece o cuidado assistencial e vital ao ser humano. A depender do caso, determina-se o âmbito da vida da pessoa no qual o apoio será conferido. É possível que se requeira apoio somente para situações jurídicas patrimoniais, somente para situações jurídicas extrapatrimoniais ou ainda somente para alguns atos específicos da vida civil. As demandas da pessoa requerente justificarão e identificarão a área na qual ela será apoiada.

A tomada de decisão apoiada será determinada pelo juiz através do procedimento de jurisdição voluntária, de competência das varas de família. Vale lembrar que, em se tratando de jurisdição voluntária, como enuncia o art. 723 do CPC/15, o juiz poderá deliberar por equidade, não estando adstrito à legalidade estrita.

A própria pessoa que necessita do apoio o requererá perante o juiz de primeira instância da justiça estadual, na comarca de sua residência, seguindo as regras de competência da curatela. No pedido, conforme art. 1783-A, caput, do CC02, indicará duas ou mais pessoas com quem mantenha vínculo de confiança para prestarlhe apoio na tomada de decisão sobre atos da vida civil.

No que toca à legitimidade para requerer a TDA, o $\$ 2^{\circ}$ do art. 1783-A da lei civil parece adotar uma posição restritiva, circunscrevendo à pessoa com deficiência o requerimento deste procedimento. Sem embargo, argumentam Nelson Rosenvald e Cristiano Chaves, numa tentativa de interpretação expansiva por tratar-se de

5.Os Estados Partes, sujeitos ao disposto neste Artigo, tomarão todas as medidas apropriadas e efetivas para assegurar às pessoas com deficiência o igual direito de possuir ou herdar bens, de controlar as próprias finanças e de ter igual acesso a empréstimos 
norma protetiva da pessoa humana, que não só a pessoa com deficiência poderá pleitear a tomada de decisão apoiada, mas os legitimados para ação de curatela também. Com lastro na tradicional regra do "quem pode mais, pode menos", sustentam que os familiares, o cônjuge ou o Ministério Público poderiam, de igual modo, requerer a tomada de decisão apoiada, consubstanciando o princípio da dignidade da pessoa humana em sua dupla acepçãoprotetiva e promocional das situações existenciais ${ }^{34}$.

Bem verdade é que só a prática judicial poderá responder sobre esse tema da legitimidade para requerimento da tomada de decisão apoiada, a depender das particularidades de cada caso. Verbi gratia, o Ministério Público pode identificar numa pessoa com deficiência, que responda a uma ação de colocação em regime de curatela, aptidão de ainda expressar sua vontade, podendo requerer, em vez da curatela, o procedimento de tomada de decisão apoiada, com a indicação dos apoiadores pela própria pessoa. No caso de alguém que já tenha sido submetido à curatela antes da vigência da Lei $n^{\circ}$ 13.146/2015, mas que tenha discernimento necessário e condições de exprimir sua vontade, é possível postular o levantamento da curatela e a determinação da TDA pelo Poder Judiciário, com a respectiva nomeação dos apoiadores.

Consoante o art. 1783-A, $\$ 1^{\circ}$, do CC02, a pessoa com deficiência e os apoiadores devem apresentar termo em que constem os limites do apoio a ser oferecido e os compromissos dos apoiadores, bem como o prazo de vigência do acordo e o respeito à vontade, aos direitos e aos interesses do apoiado. Verifica-se que o núcleo do apoio é proporcionar qualidade de vida à pessoa com deficiência, cabendo aos dois ou mais apoiadores seguirem fielmente o termo levado a juízo, tendo em consideração as reais necessidades e desejos do beneficiário.

A título ilustrativo, pode-se citar o caso das pessoas com limitações físicas ou sensoriais, tais quais a tetraplegia, a obesidade mórbida, a cegueira, as sequelas provocadas por uma AVC e outras enfermidades que as privem das condições para a realização de certos atos e negócios jurídicos sozinhas. Se eventualmente precisarem de apoio, seus apoiadores não serão representantes ou assistentes, pois não há incapacidade ou submissão ao regime de curatela. O intuito não é restringir a plena capacidade, mas promover a autonomia, sem cerceá-la.

Para prática dos atos não incluídos no termo de apoio, a pessoa conservará sua autodeterminação, não necessitando da assistência dos apoiadores. Desta forma, a tomada de decisão apoiada não pretende substituir a curatela, mas opera lateralmente a ela, em caráter concorrente e não cumulativo.

Observa-se que o legislador nada assentou sobre a remuneração do apoiador, que poderia remeter a uma decisão consignada no próprio termo de acordo. Entretanto, considerando os debates levados a efeito pela

bancários, hipotecas e outras formas de crédito financeiro, e assegurarão que as pessoas com deficiência não sejam arbitrariamente destituídas de seus bens."

${ }^{34}$ ROSENVALD, Nelson. FARIAS, Cristiano Chaves de. Curso de Direito Civil: parte Geral e LINDB, op. cit., p. 341. 
"Inclusão Internacional" ${ }^{35}$,a concepção que se apregoa quando se trata de apoio é a de embasá-lo nas pautas da solidariedade, o que exaure a discussão sobre remuneração. Isso é corroborado pelo entendimento da doutrina civil contemporânea a respeito do cuidado como valor jurídico e da promoção do princípio da solidariedade social, suscitado no preâmbulo e no art. 3º, I e IV, da Constituição Federal de 1988.

Ademais, para homologação do termo de apoio, o juiz deverá ouvir o representante do Ministério Público, bem como o próprio requerente do apoio e os apoiadores indicados, mediante colaboração de equipe multidisciplinar designada por ele, como afirma o art. 1783-A, $\$ 3^{\circ}$, do CC02. O Ministério Público atua como fiscal da ordem jurídica (custos juris), não porque haja incapaz envolvido (art. 178, CPC/15), mas por expressa disposição da lei.

As decisões tomadas pela pessoa apoiada terão validade e efeito sobre terceiros, sem restrições, desde que inseridas nos limites do apoio acordado, conforme o $₫ 4^{\circ}$ do art. 1783-A. Terceiros que mantenham relação negocial com o apoiado podem exigir a contra-assinatura dos apoiadores no instrumento de contrato ou acordo que veicular o negócio jurídico firmado. Se, relativamente aos negócios jurídicos que podem gerar riscos ou potencial prejuízo à pessoa com deficiência, houver divergências entre a pessoa apoiada e um dos apoiadores, o magistrado deliberará sobre a questão, após a oitiva do Ministério Público e colhido o laudo da equipe multidisciplinar (art. 1783-A, \$6 CC02).

Agindo o apoiador com negligência, exercendo pressão indevida sobre o apoiado ou estando inadimplente com suas obrigações, a pessoa com deficiência ou qualquer outro poderá apresentar denúncia ao Ministério Público ou ao juiz, sem prejuízo de eventual responsabilização civil ou criminal. Em sendo procedente a acusação contra o apoiador, o magistrado o destituirá do cargo, nomeando outra pessoa para a prestação do apoio, se assim for do interesse da pessoa apoiada (art. 1783-A, \$7º, CC02).

O procedimento da TDA obedecerá, residualmente, as mesmas regras da ação de curatela no que tange à prestação de contas (art. 1783-A, \$11, CC02). Pode o apoiado requerer, a qualquer momento, a cessação da medida, com extinção do termo de decisão apoiada (art. 1783-A, 9, CC02), bem como o apoiador solicitar a exclusão de sua participação no processo de tomada de decisão apoiada, sendo seu desligamento condicionado à manifestação do juiz sobre a matéria (art. 1783-A, \$10, CC02).

Por fim, nada impede que a pessoa vulnerável seja preventivamente contemplada pela tomada de decisão apoiada para depois ter sua incapacidade relativa reconhecida em processo judicial, em razão de não mais poder exprimir sua vontade, passando a ser submetida ao regime de curatela. É o exemplo da pessoa com um tipo de

\footnotetext{
${ }^{35} \mathrm{~A}$ Inclusion Internacionalé organização internacional cujos objetivos são advogar pela inclusão das pessoas com deficiência em suas comunidades e conduzir estudos e pesquisas sobre as áreas de prioridade da Convenção dos Direitos da Pessoa com
} 
deficiência de ordem mental, progressiva e degenerativa, sem perspectiva de melhora ou cura, como o Alzheimer e outras espécies de demência.

\section{Nova curatela}

Com o reconhecimento da plena capacidade civil da pessoa com deficiência e o advento do modelo da tomada de decisão apoiada, graças a determinante influência da CDPD e das mudanças legislativas diretamente manejadas pela Lei no 13.146/2015, a curatela torna-se medida extraordinária, disciplinada pelo Código Civil de 2002, pelo Estatuto da Pessoa com Deficiência e pelo Código de Processo Civil de 2015.

Nesse novo panorama normativo, busca-se ajustar a curatela à filosofia de inclusão consignada nos documentos internacionais sobre direitos humanos. Ela passa a não ser mais uma medida de substituição de vontade, e sim atribuir maior relevo às circunstâncias pessoais do próprio curatelado, especialmente às suas preferências, vínculos de afetividade e direitos fundamentais (art. 84, \$3º, EPD).

Deste modo, constrói-se um perfil funcional para curatela que estabelece o respeito às potencialidades e às "escolhas de vida que o indivíduo for capaz, concretamente, de exprimir, ou em relação às quais manifesta notável propensão" ${ }^{36}$. Toda pessoa humana é titular de situações existenciais como direito à vida, ao nome, à saúde, à integridade física, à manifestação do pensamento, cujo exercício é essencial para o desenvolvimento de sua personalidade e não carece de sua condição intelectual ( $\operatorname{art.} 85, \$ 1{ }^{\circ}$, EPD).

Tendo em vista que a incapacidade relativa tem caráter excepcional e, por conseguinte, exige prova contundente, importante sublinhar que o rol de hipóteses de incapacidade contempladas em lei é numerus clausus, ou seja, deve ser interpretado taxativamente. Logo, a decisão judicial de curatela não pode atingir valores constitucionalmente preservados em favor da pessoa, como a liberdade e a intimidade. Para a decretação da curatela, não é suficiente a mera existência de uma deficiência, pois a medida tem cunho protecionista, somente se justificando nos moldes prescritos na norma (impossibilidade de exprimir vontade, prodigalidade, embriaguez habitual ou toxicomania). A curatela deve estar respaldada na proteção da dignidade da pessoa a ser curatelada, não de terceiros.

Daí a importância de se distinguir curatela e incapacidade. Ao reconhecer a incapacidade relativa (art. 4º, II, III e IV, do CC), o juiz deferirá uma curatela cuja extensão seja proporcional à necessidade de proteção. Por exemplo, uma pessoa que, em razão de um avançado grau de deficiência ou por se encontrar em estado vegetativo,

Deficiência em todo mundo. Segundo o que se acha no sítio eletrônico: http://inclusion-international.org/wpcontent/uploads/2013/07/II-Strategic-Plan-2010-2015_June-2010.pdf. Acesso em 13.05.2016.

${ }^{36}$ PERLINGIERI, Pietro. Perfis de Direito Civil: introdução ao Direito Civil-Constitucional. Rio de Janeiro: Renovar, 2007 , p. 164. 
não consegue exprimir sua vontade, poderá ser submetida a uma curatela mais ampla, exercendo seu curador a função de representante de atos relativos a situações patrimoniais e situações existenciais. Já aquela pessoa que não exprime sua vontade, todavia guarda um determinado grau de compreensão, terá uma curatela de extensão menor, podendo manter, a título exemplificativo, os direitos políticos e sexuais.

Cristiano Chaves e Nelson Rosenvald advogam no sentido de que

"o princípio da dignidade humana $(\mathrm{CF}$, art. 1º, III) não se compatibiliza com uma abstrata homogeneização de seres humanos em uma categoria despersonalizada de incapacidades. Por isso, a sentença de curatela tem de considerar os aspectos pessoais, individualizados, daquela pessoa humana, levando em conta as suas vontades e preferências, inclusive. Com isso, a sentença de curatela há de corresponder a um projeto terapêutico individual." ${ }^{37}$

É evidente que, suprimida a classe dos absolutamente incapazes quanto aos maiores de 16 anos, não haverá mais espaço para fórmulas genéricas e pronunciamentos judiciais padronizados, isto é, decisões baseadas em modelos pré-existentes nos quais apenas se substitui o nome da parte e o número da autuação do processo. Com isso, constata-se que a sentença de curatela ostentará obrigatoriamente uma forte carga argumentativa para justificar o "processo terapêutico individualizado", além de regulamentar a extensão da intervenção sobre a autonomia privada da pessoa.

Merece atenção a possibilidade de gradação da curatela, devendo o magistrado, de ofício ou a requerimento do Ministério Público, flexibilizar seus limites ao perceber que existem elementos de compreensão e discernimento, sobretudo em relação às situações afetivas e intelectuais da pessoa com deficiência.

Não obstante o Código Processual Civil ainda intitule a ação de "interdição", a superveniência do EPD modificou sua terminologia. Por completa incompatibilidade com a vocação promocional da curatela especialmente projetada pela nova norma estatutária, é pacífico na doutrina civilista que se deve abandonar o vocábulo "interdição" por se revelar preconceituoso e estigmatizante, sinalizando uma noção restritiva de direitos. Esse "giro linguístico" tem como objetivo demonstrar que a pessoa não será interditada em seus direitos, mas curatelada por, objetivamente, não poder exprimir sua vontade de forma ponderada (art. 1767, I, CC02, com redação nova conferida pelo EPD). Assim, harmoniza-se a proteção à pessoa deficiente com o princípio da segurança jurídica.

Na perspectiva de Nelson Rosenvald,

"o vocábulo 'interdição' revela-se incompatível com o pluralismo inerente ao Estado de Democrático de Direito. Além de medida coercitiva e opressiva, que imprime uma marca indelével na pessoa, ela remete a uma sentença nulificante do exercício de situações existenciais e redutiva da complexidade e singularidade do ser humano a um quadro psíquico- o que, por si só, legitimaria a neutralização da subjetividade pelo alter ego do curador. Ao contrário, a eficácia positiva da dignidade da pessoa humana requer a potencialização da autonomia, para que cada indivíduo seja autor de sua própria biografia e

${ }^{37}$ ROSENVALD, Nelson. FARIAS, Cristiano Chaves de. Curso de Direito Civil: parte Geral e LINDB, op. cit., p. 348. 


\begin{abstract}
desenvolva o seu modus vivendi". ${ }^{38}$
Ademais, ressalta o mencionado autor que

"em verdade, o descaso terminológico demonstra a narrativa da medieval interdição como morte civil e túmulo da personalidade, postergando o inevitável porvir de uma mentalidade afinada com a funcionalização, a flexibilização e a personalização da curatela". ${ }^{39}$
\end{abstract}

Mais que uma mudança terminológica, é necessário vislumbrar uma atualização procedimental no instituto da curatela, apta a consolidar os direitos fundamentais do curatelado, valorizando sua autonomia. $\mathrm{O}$ art. $85, \$ 2^{\circ}$, do EPD esclarece a natureza excepcional da ação de curatela e reclama a aplicação do critério da proporcionalidade em sua configuração.

Quanto à legitimidade ativa para propositura da ação de curatela, essa é uma questão que merece especial atenção. Quando publicado, o CPC de 2015 tratava do tema nos seus arts. 747 e seguintes da curatela, revogando inteiramente os arts. 1768 e 1769 do CC. No entanto, durante a vacatio legis do CPC/15, sobreveio o Estatuto da Pessoa com Deficiência e alterou a redação dos arts. 1768 e 1769, ainda em vigor em virtude do cumprimento do tempo de vacância da lei processual. Daí surgiu uma situação curiosa e inesperada: a alteração de dispositivos legais que já estavam revogados por outra lei, anteriormente editada, mas que se encontrava em período de vacância.

Considerando que o Estatuto da Pessoa com Deficiência entrou em vigor antes do novo CPC, bem como que se trata de norma especial no que concerne à proteção da pessoa humana em relação ao Código de Processo Civil (que é norma geral), o ideal é desenvolver uma interpretação sistêmica, compatibilizando ambos os diplomas legais para potencializar a tutela jurídica destinada ao curatelado.

O art. 747 do CPC/15 aponta os legitimados para ação de curatela: (i) o cônjuge ou companheiro; (ii) os parentes ou tutores; (iii) o representante da entidade em que se encontra abrigado o curatelado e, por fim, (iv) o Ministério Público. Entretanto, adotando a orientação oriunda da redação do art. 1768, IV, do CC02 (não revogado pela normatividade processual), emprestada pelo EPD, tem legitimidade a própria pessoa a ser curatelada- a denominada autocuratela. Ora, ninguém mais indicado que a própria pessoa para regulamentar sua proteção. $\mathrm{O}$ pedido de submissão ao regime de curatela, certamente, não vincula o juiz, mesmo tendo sido formulado pelo próprio curatelado. Ademais, esse rol de legitimados é taxativo, sem seguir, contudo, uma ordem preferencial.

Nesse sentido, defendem os autores Cristiano Chaves e Nelson Rosenvald que o sistema jurídico ganha uma lógica estruturante. É que a própria pessoa pode realizar as chamadas diretivas antecipadas de acordo com previsão da Resolução no 1995/12 do Conselho Federal de Medicina. Se é possível a um ser humano algo mais

\footnotetext{
${ }^{38}$ ROSENVALD, Nelson. FARIAS, Cristiano Chaves de. Curso de Direito Civil: parte Geral e LINDB, op. cit., pp. 349/350.

${ }^{39}$ ROSENVALD, Nelson. FARIAS, Cristiano Chaves de, op. cit., p. 349.
} 
complexo, como recusar tratamento médico ou terapêutico infrutífero, como nos casos de pacientes terminais, com absoluta coerência, também lhe seria possível requerer judicialmente a sua curatela para assegurar-lhe proteção jurídica. ${ }^{40}$

Cabe ressaltar a novidade trazida pelo art. 747, III, do CPC, legitimando o representante da entidade em que se encontra a pessoa com deficiência para propor a ação de curatela. Nesse aspecto, a lei atentou para a realidade do processo de institucionalização das pessoas com deficiência, sobretudo de ordem mental. Não é incomum que tais pessoas, em situação de abandono por familiares, possuam direitos a serem exercidos ou protegidos, como o recebimento de um benefício previdenciário. Daí a legitimidade do representante da entidade como mecanismo de solução de um problema social. Segundo entendimento de Fredie Didier Júnior, "cuida-se de uma técnica para proteger o vulnerável. A entidade é legitimada para ação, mas isso não equivale dizer que seu dirigente será curador" ${ }^{41}$ na medida em que a nomeação deve atentar para a ordem preferencial determinada por lei (art.85, $\left.\$ 3^{\circ}, \mathrm{EPD}\right)$.

Enquanto instrumento protetivo extremo e extraordinário, a curatela, sob a nova ótica do EPD, afetará somente atos relacionados ao campo patrimonial e negocial (art. 85, caput, da Lei no 13.146/15), não prejudicando o direito ao próprio corpo, à sexualidade, ao matrimônio, à privacidade, à educação, à saúde, ao trabalho e ao voto (art. 85, \$1 ${ }^{\circ}$, EPD). Dentre outras razões, isso explica o motivo pelo qual a Lei no $13.146 / 2015$ é considerada um marco revolucionário no sistema jurídico brasileiro: é o primeiro diploma legal a distinguir claramente as situações/interesses patrimoniais dos existenciais.

A tese de que a curatela não deve interferir nos interesses existenciais do curatelado já era patrocinada por alguns doutrinadores antes mesmo do advento da Convenção dos Direitos da Pessoa com Deficiência. Paulo Lôbo sustenta que a capacidade para o exercício dos direitos não patrimoniais, associados ao estado da pessoa humana, tais como o direito à identidade pessoal e ao nome, não são alcançadas pela incapacidade absoluta ou relativa. Nesse sentido, afirma que "o juiz poderá conter a interdição apenas aos atos de emprestar, transigir, da quitação, alienar, hipotecar, demandar e ser demandado, e aos atos que não sejam de mera administração". ${ }^{42}$

Na mesma linha de raciocínio, Célia Barbosa Abreu assevera que

"numa perspectiva contemporânea, somente para os interesses patrimoniais é justificado isolar o momento da titularidade do direito (isto é, o gozo) daquele da sua atuação (o chamado exercício). O mesmo não ocorre em relação aos interesses existenciais. Quando se cuida de direito conferido ao homem com a finalidade de promover seu desenvolvimento enquanto pessoa humana, não há sentido em reconhecê-lo abstratamente sem lhe conceder também a possibilidade de exercê-lo. Essa observação concerne não apenas a situações

\footnotetext{
${ }^{40}$ Op.cit., pp. 351 e 352.

${ }^{41}$ WAMBIER, Teresa Arruda Alvim; DIDIER JÚNIOR, Fredie; TALAMINI, Eduardo; DANTAS, Bruno (coord). Breves comentários ao novo Código de Processo Civil. São Paulo: RT, 2015, p. 1735.

${ }^{42}$ LOBO, Paulo. Direito civil: parte geral. São Paulo: Editora Saraiva, 2010, p. 119.
} 
definidas como direitos personalíssimos, mas também a atos ou negócios que representam seu exercício, assim como os inúmeros direitos e liberdades fundamentais consagrados no texto constitucional." ${ }^{43}$

Ainda, adverte Pietro Perlingieri que o estado pessoal patológico, mesmo que permanente, não sendo absoluto ou total, "não se pode traduzir em uma série estereotipada de limitações e proibições que, no caso concreto, isto é, levando em conta o grau e qualidade do deficit psíquico, não se justificam e acabam por representar camisas de força totalmente desproporcionadas e, principalmente, contrastantes com a realização do pleno desenvolvimento da pessoa". ${ }^{44}$

Conquanto se reconheça à pessoa com deficiência a titularidade de situações existenciais e a importância do seu exercício para o desenvolvimento da personalidade, é necessário ponderar sobre se competiria ao curador poderes de representação e possibilidade de intervenção no âmbito de interesses existenciais nas hipóteses em que o sujeito for completamente faltoso de discernimento ou carente do indispensável entendimento para determinadas atividades extrapatrimoniais.

Como a pessoa totalmente impossibilitada de exprimir sua vontade, logo, relativamente incapaz, poderia ser somente assistida por seu curador e não representada? Conclui-se que o curador deve ser efetivo representante da pessoa com deficiência que esteja completamente inapta a expressar sua vontade pelas circunstâncias fáticas, sob pena de inviabilizar o próprio exercício dos direitos do curatelado e a tutela jurídica que a lei lhe confere. Assim sendo, faz-se mister dissociar as técnicas da representação e da assistência dos institutos das incapacidades absoluta e relativa, respectivamente. Em verdade, um relativamente incapaz, por força da norma estatutária, que não consiga expressar sua vontade, poderá se valer da representação ou da assistência, sempre na proporção de suas necessidades.

A depender das singularidades de cada pessoa, bem como de sua condição física, psíquica e intelectual, após a oitiva do Ministério Público, a realização de perícia médica obrigatória por equipe multidisciplinar e a entrevista com a própria pessoa a ser submetida ao regime de curatela (arts. 751, caput, e 753 , capute $\$ 11^{\circ}$, todos do CPC/15), o magistrado proferirá sentença que se traduzirá num autêntico projeto terapêutico individualizado, nomeando o curador, fixando os limites da curatela proporcionalmente às demandas do curatelado e apreciando as características pessoais, habilidades, potencialidades, desejos e preferências do relativamente incapaz.

A extensão da curatela poderá assumir três formas diferentes: (i) o curador pode se apresentar como um representante para todos os atos jurídicos porque o curatelado não tem condições de praticá-los, sequer em conjunto- no caso de alguém em coma ou inteiramente desprovido de discernimento; (ii) o curador pode ser representante para certos atos e assistente para outros, em um regime misto, reconhecendo no curatelado aptidão

\footnotetext{
${ }^{43}$ ABREU, Célia Barbosa. Capacidade Civil, Discernimento e Dignidade do Portador de Transtorno Mental, op. cit., pp. 9/10.

${ }^{44}$ PERLINGIERI, Pietro. Perfis do Direito Civil: introdução ao Direito Civil-Constitucional, op. cit., p. 164.
} 
de praticar alguns atos conjuntamente com seu curador, mas não em outros, nos quais seria representado, por exemplo, nos atos patrimoniais; (iii) o curador operará sempre como assistente, na hipótese em que o curatelado tem condições de praticar todo e qualquer ato, desde que devidamente assistido, para sua proteção. ${ }^{45}$

Por outro lado, é certo que os poderes do curador, ainda que coincidam com a técnica da representação legal, não englobam os direitos políticos ou trabalhistas, bem como as questões relativas ao estado civil do curatelado. Nessa linha, Joyceanne Bezerra de Menezes discorda, inclusive, da aplicação do art. 1582, parágrafo único, do CC, que confere legitimidade ativa ao curador para propositura do divórcio ou separação. Quando muito, a autora aduz que este poderia contestar tais ações. ${ }^{46}$

Com efeito, a nova concepção de curatela introduzida pela Lei no 13.146/15 visa evitar a coisificação da pessoa submetida a este regime, que não pode ter sua integridade psicofísica prejudicada pela atuação inadequada do curador. A intervenção do curador será sempre com o intuito de concretizar o interesse fundamental do curatelado, compreendido por suas preferências genuínas, convicções, percepções de mundo. Se a pessoa curatelada houver nascido sem capacidade volitiva (ou capacidade de querer), não registrando marcas de sua personalidade e modo de viver, o curador deverá guiar-se pelos princípios da beneficência, adotando padrões respeitáveis à dignidade da pessoa humana, na tentativa de satisfazer, sempre que possível, as inclinações e relações afetivas e comunitárias daquela. ${ }^{47}$

Ainda no que se refere à nomeação do curador, vale lembrar a possibilidade de fixação de curatela compartilhada, no mesmo padrão da guarda compartilhada, conforme texto do art. 1775-A, acrescentado pelo EPD ao CC02.

Por fim, cabe salientar a possibilidade de levantamento de curatela, prevista no caput do art. 756 do $\mathrm{CPC} / 15$, em concordância com a redação do art. $84, \$ 3^{\circ}$, do Estatuto que, em sua parte final, dispõe que a curatela "deverá durar o menor tempo possível". Se, posteriormente ao deferimento judicial da curatela, cessa a causa que a determinou e a pessoa com deficiência recupera a plenitude de sua manifestação de vontade, poderá ser levantado o mecanismo protetivo para retomada da plena capacidade jurídica. Isso se coaduna com as diretrizes da nova curatela, que imputam ao curador deveres não apenas de administração de bens, mas também de cuidado assistencial à pessoa curatelada para que, sendo factível, recupere a plenitude de sua saúde o mais breve possível.

\footnotetext{
${ }^{45}$ ROSENVALD, Nelson. FARIAS, Cristiano Chaves de. Curso de Direito Civil: parte Geral e LINDB, op. cit., p. 348.

${ }^{46}$ MENEZES, Joyceane Bezerra de. O direito protetivo no Brasil após a convenção sobre a proteção da pessoa com deficiência: impactos do novo CPC e do Estatuto da Pessoa com Deficiência, op. cit., p.22.

${ }^{47}$ BARBOSA-FOHRMANN, Ana Paula. Algumas reflexões sobre os fundamentos dos discursos de direitos humanos e de justiça social para pessoas com deficiência mental ou cognitiva severa ou extrema. Revista de Direitos Fundamentais \& Justiça. Ano 7, $\mathrm{n}^{\circ}$ 22, 2013, jan./mar., P. PUCRS, 20 80 $97 . \quad$ Disponível <http://www.dfj.inf.br/Arquivos/PDF_Livre/22_Doutrina\%20Nacional\%202_OK.pdf> Acesso em 23.07.2016.
} 


\title{
NOTA CONCLUSIVA
}

A abordagem desenvolvida neste trabalho teve como fundamento a noção de cuidado como uma atitude de ocupação, preocupação e responsabilização com o outro, distanciando-se do viés paternalista, levando em consideração o envolvimento com outro - ideia de alteridade -, no lugar de submissão à vontade alheia. A solidariedade constitucionalmente assegurada tem por finalidade a proteção e promoção da existência digna, justa e igualitária de todas as pessoas humanas, sem qualquer tipo de exclusão ou marginalização.

A condição jurídica atual das pessoas com deficiência, no âmbito do Direito brasileiro, é demonstração clara da incidência das normas constitucionais de direitos fundamentais nas relações privadas, em especial no que tange ao regime jurídico das (in) capacidades.

\section{DISABILITIES AND DISABLED PEOPLE REGIME}

\begin{abstract}
The paper scope is to study the subject of civil capacity and its implications, considering the substantial legal changes implemented by the Convention on the Rights of the Person with Disabilities and the Statute of the Person with Disabilities (Act no 13.146/2015), which resulted in a rereading of the incapacity's theory in light of inclusion of people with disability and promotion of their dignity and basic rights. Furthermore, it discusses the redefinition of guardianship and the insertion of supported decision-making in Brazilian law, focusing on the existential view of the person.
\end{abstract}

Keywords: Civil capacity. Person with disabilities. Inclusion. Guardianship. Supported decision-making.

\section{REFERENCIAS}

ABREU, Célia Barbosa. Curatela: uma Proposta de Leitura Constitucional do Artigo 1.772 do Código Civil Brasileiro. Revista Brasileira de Direito das Famílias e Sucessões, Belo Horizonte, v. 7, 2009.

Capacidade Civil, Discernimento e Dignidade do Portador de Transtorno Mental. Revista Brasileira de

Direito das Famílias e Sucessões, Belo Horizonte, v. 8, 2009.

ABREU, Célia Barbosa. Curatela e interdição civil. Rio de Janeiro: Lumen Juris, 2009.

AMARAL, Francisco. Direito Civil: Introdução. 5a ed. Rio de Janeiro:Renovar, 2003.

BARBOSA-FOHRMANN, Ana Paula. Algumas reflexões sobre os fundamentos dos discursos de direitos humanos e de justiça social para pessoas com deficiência mental ou cognitiva severa ou extrema. Revista de Direitos Fundamentais \& Justiça. Ano 7, no 22, 2013, jan./mar., PUCRS, p. 80-97. Disponível em: 
<http://www.dfj.inf.br/Arquivos/PDF_Livre/22_Doutrina\%20Nacional\%202_OK.pdf> Acesso em 23.07.2016.

CHINELlATO, Silmara Juny (coord). Código Civil interpretado. $3^{a}$ ed. Org. Costa Machado. São Paulo: Manole, 2010.

COSTA FILHO, Waldir Macieira da. Reflexões sobre a Lei n. 13.146, a concepção da deficiência e capacidade legal e tomada de decisão apoiada. Revista do Ministério Público do Estado do Pará. v. 9, n. 9. Belém: Ministério Público do Estado do Pará, 2016.

DWORKIN, Ronald. Domínio da vida: aborto, eutanásia e liberdades individuais. São Paulo: Martins Fontes, 2003.

FERRAJOLI, Luigi. Los fundamentos de los derechos fundamentales. Madrid: Editorial Trotta, 2001.

GOMES, Orlando. Raízes históricas e sociológicas do Código Civil brasileiro. São Paulo: Martins Fontes, 2003.

LEITE, Flávia Piva Almeida; RIBEIRO, Lauro Luiz Gomes; COSTA FILHO, Waldir Macieira (coords.). Comentários ao Estatuto da Pessoa com Deficiência. São Paulo: Saraiva, 2016.

LOBO, Paulo. Direito civil: parte geral. São Paulo: Editora Saraiva, 2010.

MENEZES, Joyceane Bezerra de. O direito protetivo no Brasil após a convenção sobre a proteção da pessoa com deficiência: impactos do novo CPC e do Estatuto da Pessoa com Deficiência. Civilistica.com. Rio de Janeiro, a. 4, n. 1, jan.- jun./2015, p.5. Disponível em:<http://civilistica.com/wp-content/uploads/2016/01/Menezescivilistica.com-a.4.n.1.2015.pdf> Acesso em 10.04.2016.

MORAES, Maria Celina Bodin de. Na medida da pessoa humana. Estudos de direito civil-constitucional. Rio de Janeiro: Renovar, 2010.

A caminho do Direito Civil Constitucional. Revista de Direito Civil. São Paulo: RT, n.65, jul./set. 1993. NADER, Paulo. Curso de Direito Civil: Parte Geral. Rio de Janeiro: Forense, 2003.

PERLINGIERI, Pietro. Perfis de Direito Civil: introdução ao Direito Civil-Constitucional. Rio de Janeiro: Renovar, 2007.

RESENDE, Ana Paula Crosara; VITAL, Flávia Maria de Paiva (coords). A Convenção sobre Direitos das Pessoas com Deficiência comentada. Brasília: Secretaria Especial dos Direitos Humanos, 2008. Disponível em: $<$ http://www.governoeletronico.gov.br/documentos-e-

arquivos/A\%20Convencao\%20sobre\%20os\%20Direitos\%20das\%20Pessoas\%20com\%20Deficiencia\%20Come ntada.pdf>. Acesso em 03.09.2016.

ROSENVALD, Nelson. FARIAS, Cristiano Chaves de. Curso de Direito Civil: parte Geral e LINDB. Salvador: Ed. JusPodivm, 2016.

STILL ALICE.Direção: Richard Glatzer eWash Westmoreland. Produção: Lynn Appelle, Declan Baldwin, James Brown e outros. Roteiro: Lisa Genoveva, Richard Glatzer eWash Westmoreland. Intépretes: Julianne Moore, Alec 
Baldwin, Kristen Stewart, Kate Bosworth, Hunter Parrish, Stephen Kunken e outros. New York: Lutzus-Brown; Killer Films; BSM Studio; Big Indie Pictures; Shriver Films. 1 filme (101 min), 2014.

TARTUCE, Flávio. Direito Civil, v.1: Lei de Introdução e Parte Geral. 12ª ed. rev., atual. eampl. Rio de Janeiro: Forense, 2016.

TEIXEIRA, Ana Carolina Brochado. Deficiência Psíquica e Curatela: Reflexões Sobre o Viés da Autonomia Privada. Revista Brasileira de Direito das Famílias e Sucessões, Belo Horizonte, v. 7, 2009.

WAMBIER, Teresa Arruda Alvim; DIDIER JÚNIOR, Fredie; TALAMINI, Eduardo; DANTAS, Bruno (coord). Breves comentários ao novo Código de Processo Civil. São Paulo: RT, 2015.

World Health Organization 2012.Dementia: a public health priority, p.4. Disponível em: <http://apps.who.int/iris/bitstream/10665/75263/1/9789241564458_eng.pdf> Acesso em 02/07/2016.

Trabalho enviado em 24 de julho de 2018.

Aceito em 29 de julho de 2018. 